ANMELDELSER 
KAREN-MARGRETHE

SIMONSEN

\section{MIGRATIONS- LITTERATUR}

SØREN FRANK, 2008

Migration and Literature

(New York: Palgrave MacMillan, 248 sider)

Litteratur har altid været knyttet til bevægelse og rejser, lige fra Homer og Vergil til Cervantes og Defoe, men 'migrationen' som sådan, hævder Søren Frank i sin bog Migration and Literature, forstået som globaliseret socialt levevilkår, er et uomtvisteligt moderne fænomen, der først for alvor sætter sig igennem efter 2. verdenskrig. Hér bliver det til gengæld så dominerende, at selv mennesker, der ikke rejser nogen steder hen, har en migratorisk bevidsthed, og det gælder også litteraturen. Som Søren Frank skriver i indledningen: "Pointen er, at hvad enten vi prioriterer den sociale kontekst eller den litterære form eller indholdet, så bliver distinktionen mellem migrante og ikke-migrante forfattere stadig sværere at opretholde." ${ }^{\prime}(2)$. Vi er alle migranter enten i bogstavelig forstand eller i overfort forstand, fordi vores lokale og/eller nationale forankring er udfordret.

I modsætning til, hvad Søren Frank skriver, mener jeg godt, at det kan dis-

I Alle citater er oversat fra engelsk til dansk af mig selv (KMS). kuteres, om migration er så moderne, som det ofte hævdes, og om det giver mening at tale om hele kulturen som migratorisk. Ikke desto mindre giver Søren Frank i sin bog en meget overbevisende og nyttig fremstilling af migration som begreb og som analyseredskab i forhold til litteraturen.

Hovedsubstansen i bogen er næranalyser af udvalgte værker af fire sværvægtere: Günter Grass, Milan Kundera, Salman Rushdie og, lidt mere overraskende, af Jan Kjærstad. Alle fire forfattere bliver læst ind i en europæisk kontekst. Frank ønsker nemlig at løsrive diskussionen af migration fra den postkoloniale kontekst og i stedet lade migrationen stille spørgsmål ved den europæiske enhed indefra. Som Frank skriver, så er intentionen at give et billede af Europa som "uafsluttet potentialitet" (9). Migrationsbegrebet skal altså ikke alene forklare enkelte forfatterskaber. Det skal være med til at forny vores europæiske selvforståelse og identitet. Det er store ambitioner, som kun vanskeligt kan opfyldes inden for en bogs rammer. Sympatisk nok starter Frank ikke med det europæiske storscenarium. Han ønsker tværtimod først og fremmest at vise i praksis, hvad migration er, både tematisk og formelt $\mathrm{i}$ konkrete litterære værker.

I indledningen lægger Frank ud med at opstille 8 kriterier for migrationslitteratur: fem tematiske og tre stilistiske. De fem tematiske er: I. forfatterbiografi (som altså stadig tæller med som kriterium), 2. romanpersoner, 3. nation og nationalisme, 4. europæiskhed og romanen som europæisk genre samt 5. globalisering. De tre 
stilistiske kriterier er I. fortæller/udsigelsesstrategier, 2. komposition/narrativ form og 3. sprog. Som man kan se, er kriterierne ikke formuleret som afkrydsningskriterier, men er egentlig blot områder, som kan have betydning for vurderingen af det migratoriske i de enkelte forfatterskaber. Franks læsningsmetode er reelt mindre systematisk og mere dialogisk. Heldigvis kan man sige.

Frank giver sig tid til at fordybe sig i nogle gevaldigt interessante diskussioner om de valgte værker, som ad omveje faktisk også viser sig at være interessante for diskussionen af migration. Lad mig give et par eksempler. Når Frank f.eks.diskuterer Salman Rushdie, som ingen vil tvivle på, kan beskrives som migratorisk forfatter, så tager Frank fat på hans nationalismetænkning og giver dermed den glade globalisering, som ofte læses ind i Rushdie, modstand. Tilsvarende insisterer Frank på, at Günter Grass' Danzig i Bliktrommen, som ofte fremhæves for sin konservative og lukkede atmosfære, er multikulturel og har et dynamisk potentiale. Kunderas værker læses ikke kun som dobbeltkulturelle og splittede mellem tjekisk og fransk kultur, han prøver her at efterspore en egentlig kosmopolitisk patriotisme, og endelig læses den fastboende Jan Kjærstad som en migratorisk forfatter pga. det spændingsfyldte samspil mellem en norsk og en global bevidsthed og den multiperspektiviske narrative tilrettelægning. Denne 'modstandens æstetik', som Franks læsninger følger, gør bogen til en meget læseværdig oplevelse.

Hans metodiske Ansatzpunkt i migration virker som et vellykket prisme, der kan bruges til at diskutere bevægelser mellem centrale begreber inden for udvalgte forfatterskaber. Det virker også overbevisende, at migration er et centralt tema i forståelsen af megen ny litteratur. Det svageste punkt er dermed selve afgrænsningen af fænomenet migrationslitteratur.

Som Frank siger i indledningen, så refererer begrebet migrationslitteratur til "alle de litterære værker, der er skrevet i en migrationsperiode" (2). Hvis dette er tilfældet, så skal en definition være i stand til at inkludere selv værker, der er skrevet af fastboende, som ikke tematiserer migration. Det er et meget vidt begreb, og derfor tilføjer Frank lidt defensivt, men klogeligt: "eller i det mindste værker, som kan siges at reflektere over migration” (2).

Et af de vigtigste ærinder i bogen er at opbygge et litteraturkritisk begreb om migration, som ikke er forfatterbiografisk orienteret. Hvis han skulle tage de fulde konsekvenser af sin videnskabelige testcase, nemlig Jan Kjærstad, og af den radikale tese, han er på vej til at udkaste $\mathrm{i}$ indledningen, hvor al litteratur skrevet $i$ en migratorisk periode er migrationslitteratur, så skulle han helt opgive forfatterbiografien som indgang til forståelsen af litteraturen. Søren Frank understreger flere gange, at forfatterbiografien ikke spiller nogen rolle som et afgørende parameter. Alligevel dukker den op i hvert eneste kapitel som en skyggepartner, og den indgår stadig som et af de otte kriterier for migrationslitteratur.

Der er altså en smule vaklen, når det gælder konsekvens i afgrænsningen af migrationslitteratur, men dette problem står Frank ikke alene med. 
Det gælder også afgrænsningen og forståelsen af verdenslitteratur, eksillitteratur og rejselitteratur, som er beslægtede begreber, som Frank også diskuterer med. Fordelen ved begrebet migrationslitteratur i forhold til f.eks. begrebet verdenslitteratur er netop, at det tillader en problemorienteret fokusering på ganske bestemte bevægelser inden for den nye litteratur.

Man kunne ønske sig, at Frank havde uddybet konsekvenserne af migrationslitteraturen for den europæiske selvforståelse mere. For hvorfor skulle migration være et særligt europæisk tema? - eller skal det forstås således, at europæisk litteratur har særlige vinkler på det migratoriske? Frank hævder, at den europæiske romangenre har en europæisk karakter, men dette spor bliver ikke samlet op i afslutningen, og det fremstår blot som gådefuldt og kontraintentionelt, når Frank hævder, at man ikke kan forstå den europæiske roman uden at forstå det britiske imperium (s. I4), for hermed trækkes diskussionen af det migratoriske tilbage til den postkoloniale diskurs.

Ikke desto mindre er bogen et vældigt godt og interessant bud på en refleksion over begrebet migration, og en af bogens store styrker er, at den ikke bare postulerer migrationen, men afprøver, diskuterer og reflekterer over begrebet i sine tætte læsninger. Jeg håber, den vil blive læst af alle, der interesserer sig for globalisering og litteratur.

Karen-Margrethe Simonsen er lektor ved Institut for Astetik og Kommunikation, Afdeling for Litteraturhistorie, Aarhus Universitet. 